
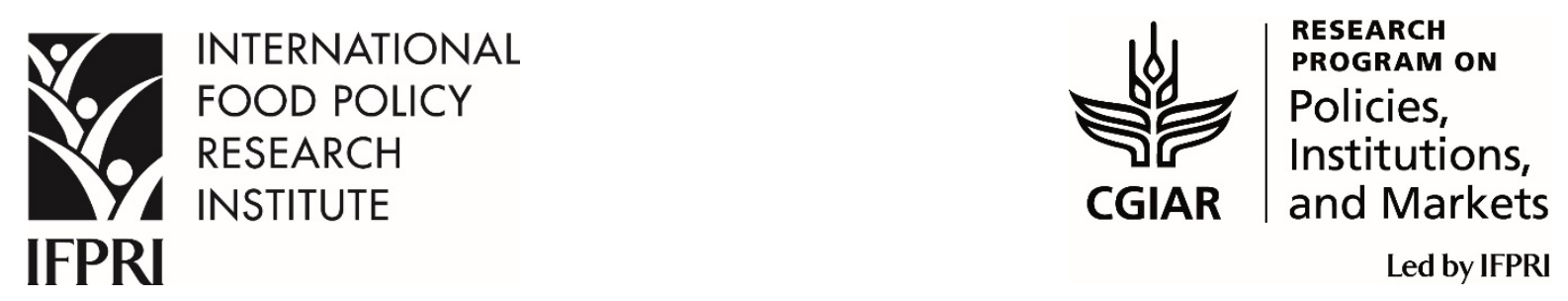

IFPRI Discussion Paper 01938

June 2020

\title{
Negotiating the Social Contract in Urban Africa \\ Informal Food Traders in Ghanaian Cities
}

Danielle Resnick

Bhavna Sivasubramanian

Development Strategy and Governance Division 


\section{INTERNATIONAL FOOD POLICY RESEARCH INSTITUTE}

The International Food Policy Research Institute (IFPRI), a CGIAR Research Center established in 1975, provides research-based policy solutions to sustainably reduce poverty and end hunger and malnutrition. IFPRI's strategic research aims to foster a climate-resilient and sustainable food supply; promote healthy diets and nutrition for all; build inclusive and efficient markets, trade systems, and food industries; transform agricultural and rural economies; and strengthen institutions and governance. Gender is integrated in all the Institute's work. Partnerships, communications, capacity strengthening, and data and knowledge management are essential components to translate IFPRI's research from action to impact. The Institute's regional and country programs play a critical role in responding to demand for food policy research and in delivering holistic support for country-led development. IFPRI collaborates with partners around the world.

\section{AUTHORS}

Danielle Resnick (d.resnick@cgiar.org) is a Senior Research Fellow in the Development Strategy and Governance Division of the International Food Policy Research Institute IFPRI), Washington, DC.

Bhavna Sivasubramanian (bhavna.sivasubramanian@ifmr.ac.in) is a Research Associate at J-PAL South Asia and formerly a Research Analyst at IFPRI.

\footnotetext{
Notices

${ }^{1}$ IFPRI Discussion Papers contain preliminary material and research results and are circulated in order to stimulate discussion and critical comment. They have not been subject to a formal external review via IFPRI's Publications Review Committee. Any opinions stated herein are those of the author(s) and are not necessarily representative of or endorsed by IFPRI.

${ }^{2}$ The boundaries and names shown and the designations used on the map(s) herein do not imply official endorsement or acceptance by the Intemational Food Policy Research Institute (IFPRI) or its partners and contributors.

${ }^{3}$ Copyright remains with the authors. The authors are free to proceed, without further IFPRI permission, to publish this paper, or any revised version of it, in outlets such as joumals, books, and other publications.
} 


\begin{abstract}
How do cities build a social contract with their diverse constituencies and foster political trust among the urban poor? This study focuses on informal traders, who constitute a major source of food security and employment in urban Africa. Centered on Ghana's three main cities, we analyze interviews with metropolitan policymakers and a survey of approximately 1,200 informal traders. The findings show that expectations about reciprocity and procedural justice play a key role in shaping the probability of trusting one's local government. Lower levels of trust were associated with disappointment over the lack of benefits that accompany tax payments to local assemblies. Moreover, those who had experienced harassment by city authorities were less likely to trust their local government. The analysis demonstrates that political trust at the subnational level deserves greater empirical attention, especially as countries continue to deepen decentralization initiatives and cities strive to meet global development goals around inclusivity.
\end{abstract}

Keywords: Cities, Ghana, informal economy, political trust, social contract, urbanization 


\section{Acknowledgments}

The authors thank John Agandin and Mekamu Kedir for excellent research support. For the implementation of the surveys with informal food traders, they are very grateful to the Center for Democratic Development in Ghana, especially the leadership of Mavis Dupork Zome, Daniel Attoh Armah, and Kakra Adu. They greatly appreciate funding for this research that was provided by USAID through its support to IFPRI's Ghana Strategy Support Program and by the Policies, Institutions, and Markets (PIM) program of the Consultative Group of International Agricultural Research. The research received ethics approval through IFPRI's Institutional Review Board under approval number DSGD-18-0522. The survey data discussed in the paper is available on Harvard's Dataverse at: https://doi.org/10.7910/DVN/DKDUU9. Any errors remain those of the authors. 


\section{Introduction}

Urbanization and decentralization are proceeding apace in much of the developing world, resulting in a host of service delivery needs and policy challenges. Due to international efforts to promote "inclusive cities" as a part of the Sustainable Development Goals and the New Urban Agenda, there is growing emphasis on the role of city governments in providing rights and benefits to citizens. ${ }^{1}$ Yet, how do cities build a social contract with their very diverse constituencies and foster political trust among the urban poor?

The concept of the social contract has a long lineage, dating back to Plato but expanded upon substantially by Hobbes, Locke, Rousseau, Hume, and Rawls, among other political philosophers. Fundamentally, a social contract is an implied bargaining process between states and citizens about their mutual roles and responsibilities. For instance, citizens need physical security and services from the state and, in turn, they agree to pay taxes and acknowledge the state's ability to enforce rules and have a monopoly over the legitimate use of violence (Hickey and King 2016). Traditionally, the concept of the social contract has inferred a negotiation between citizens and the nation-state. But, with the proliferation of subnational governments, and the growing prominence of cities and mayors, it is increasingly necessary to consider alternative units of analysis beyond the nation-state (Bell and De-Shalit 2012). In fact, citizens often are simultaneously navigating multiple social contracts with different entities across levels of government.

This is particularly true for citizens in cities of sub-Saharan Africa where socioeconomic inequalities are pronounced (UN 2010). ${ }^{2}$ A small middle-class whose income growth is critical

\footnotetext{
${ }^{1}$ SDG number 11 focuses on inclusive cities.

${ }^{2}$ Hereafter, referred to just as Africa.
} 
to expanding city coffers often is juxtaposed against a large share of the population living in informal settlements and working in the informal economy. Consequently, local governments face trade-offs in deciding whose preferences to prioritize; for instance, privatizing public space may attract more business investment but also result in further geographic marginalization of already vulnerable populations, raising questions about who has a genuine "right to the city" (Brown, Msoka, and Dankoco 2015; Lefebvre 1968).

This paper focuses on the social contract between city governments and the urban poor, with a specific focus on informal traders who vend goods within open-air markets and along streets. Globally, more than 40 percent of the world's urban labor force works in the informal economy, though the share is as high as 80 percent in Africa. ${ }^{3}$ Within the region, more than three-fourths of the labor force is specifically concentrated within the services sector, which encompasses trading activities (ILO 2018). Despite the many benefits of informal trade for the livelihoods of the urban poor and their food security (Battersby and Crush 2015; Crush and Young 2019), they often face a contentious relationship with local governments, including forced removals, arrests, and confiscation of goods. The problem is most pronounced among informal food traders due to the implications of their activities for consumer food safety. Indeed, erratic crackdowns and campaigns against informal food traders in African cities are well-documented, often justified as a way to uphold law and order and enforce hygiene standards for other city residents (Bromley 2000; Resnick 2019; Skinner 2019; Smit 2016).

Empirically, the paper focuses on informal food traders in Ghana's three largest cities, Accra, Kumasi, and Tamale. Semi-structured interviews collectively were conducted with more

\footnotetext{
${ }^{3}$ Informal employment is classified as those who lack social security, paid annual leave, or paid sick leave. Such employees may operate in enterprises that are not registered, do not pay social security or tax wages, and have five employees or less (see ILO 2018).
} 
than a dozen policymakers involved in overseeing informal trade within local government across all three cities in March-April 2018. Efforts were made to interview policymakers involved in managing public and environmental health, finance, physical planning, public relations, waste management, and public space. This view from government officials was complemented with a survey with over 1,200 traders.

The paper first discusses the concept of the social contract and argues that the strength of such contracts is captured through the lens of political trust, which proxies for citizens' confidence in their governments. Then, different drivers of political trust among informal traders are examined. Subsequently, we detail the governance of informal food traders in Ghana, including the de-jure rights and responsibilities that are expected between traders and their local governments, known as Metropolitan, Municipal, and District Assemblies (MMDAs). We then turn to analyzing why traders demonstrate significant variations in trust across the three cities. Collectively, the findings suggest that where reciprocity and procedural justice are perceived as absent, traders' trust in their city governments is lower. Across all three cities, traders are less likely to trust their MMDA if they have paid their requisite fees to authorities but do not perceive they have received any benefit in return. In Kumasi, where successive mayors have had particularly draconian policies towards traders, experience with harassment by authorities further undermines political trust. Moreover, we show that trusting one's MMDA has a significant correlation with other types of actions, including a trader's willingness to pay more money to address a priority area of service delivery within the market where $\mathrm{s} / \mathrm{he}$ is based.

There are at least two main contributions that emerge from the findings. First, to our knowledge, this is one of the first studies to examine political trust in African city governments. In doing so, it builds on a small but burgeoning field of research in Asia, Europe, and the United 
States on drivers of political trust at the subnational level (Fitzgerald and Wolak 2016; Rahn and Rudolph 2005; Tang and Huhe 2016; Wolak and Palus 2010; Wu and Wilkes 2018).These studies recognize that national and local trust may operate independently, and this is especially true in settings where local governments have substantial autonomy to make and implement policies in specific domains (see Jennings 1998). Understanding drivers of trust at the local level could provide insight into the legitimacy of decentralization efforts that have swept through the developing world, albeit in fits and starts, over the last two decades. Secondly, in Africa, trust has been found to be lower in urban than in rural areas (Brinkerhoff, Wetterberg, and Wibbels 2016), and a common pattern is that urbanites are more likely to support opposition parties rather than the incumbent (Harding 2020). Examining the types of experiences specific constituencies have with their city governments, and their implications for trust, may help uncover why such patterns emerge in the aggregate.

\section{The Social Contract and Inequality}

Social contracts broadly refer to the protection of rights and provision of resources between states and citizens (Hickey and King 2016). It has been argued that they underlie the shape and extent of social protection programs, such as food subsidies, safety nets, and welfare systems (Devereux 2013; Haggard and Kaufman 2009; Hickey 2012). Similarly, the nature of the social contract has been used to explain rates of tax mobilization and evasion (Moore, Prichard, and Feldstad 2018; Prichard 2015) as well as the resilience of peace-building initiatives (McCandless 2018). Broken social contracts, exemplified by protest, conflict, or a major rupture from the status quo often reveal fundamental concerns about state legitimacy. For example, the Arab Spring in 2011, recurrent service delivery protests in South Africa, and the East Asian financial crisis are just a few events that have been attributed to the rupture of a social contract 
(see Devarajan and Ianchovichina 2018; Haggard and Birdsall 2002; Tshitereke 2006).

The concept can be traced to political theorists of the $17^{\text {th }}$ and $18^{\text {th }}$ centuries who essentially argued that the state's power should be impartially exercised for the public good (Freeman 2012). ${ }^{4}$ The social contract therefore is a voluntary agreement of free agents in society that they will subject themselves to political authority if certain conditions are in place to continue to assure their freedom and equality (Freeman 2012). Like any contract, it requires reciprocity — both parties need to promise to provide one thing in return for another—and this reciprocity is conditional, meaning that one's promise to perform an action occurs if and only if the other party carries out his/her promise (Lessnoff 1986). In the perspective advanced by John Locke, such conditions included the state protecting people from harm and defending their property rights (Hickey 2012).

But, the impartiality of such exchanges is grounded in subjective assessments of the state's behavior vis-à-vis citizens' desires and position in society. For Jean-Jacques Rousseau, the state's duty was to promote justice in such exchanges based on the preferences of the "general will" (see Hickey 2012). Rawls (1971) later argued that the principles of the social contract should be based on procedural justice guided not by actual preferences but by those derived under a "veil of ignorance" whereby economic and social inequalities are rearranged to be of the greatest benefit to the least advantaged.

While there are many critiques of social contract theory in its traditional exposition, two are relevant for this paper. One is that society is not homogeneous and therefore, it is difficult to have a unified "general will"; it is nearly impossible for the same hypothetical contract to govern

\footnotetext{
${ }^{4}$ Political theorists' views of the social contract are much more varied than space allows. See Freeman (2012) for a substantive review of the similarities and differences across Locke, Rousseau, Hobbes, Rawls, and Hume on the concept of the social contract.
} 
relations with everyone. This has been the basis of critiques of the concept from feminist and race conscious philosophers such as Mills (1997) and Pateman (1988), respectively. They argue that the notion of a society comprised of free individuals who negotiate with the state ignores that historically, the confines of patriarchy and racism essentially excluded women and racial minorities from expecting impartial treatment from the state. Similarly, socioeconomic inequalities can distort individuals' ability to exercise reciprocity and enforce conditionality with the state. In many countries, the poor and those in the informal economy usually have unequal bargaining power with the state. They are expected to adhere to regulations without receiving much in return (Agarwala 2013; World Bank 2019b), unless they demand greater redistribution and security through dramatic means such as mass protest or political regime change. Rousseau (1997: 77-78) implicitly recognized the challenge of inequality by stating that the ideal setting for his social contract is "one which is neither rich nor poor."

Second, although social contract theory traditionally focused on the nation-state as the main unit of analysis, recent work highlights that there are multiple public authorities-including chiefs, warlords, donors, and NGOs_- who constantly forge relationships of reciprocity with a diverse range of constituencies (see De Herdt, Titeca, and Wagemakers 2012; Nugent 2010). As both decentralization and urbanization proceed apace, enhancing the political, administrative, and fiscal autonomy of subnational governments (Stren 2012), cities increasingly represent important sites of alternative forms of political authority. Indeed, since citizens most directly engage with their local rather than national government on a regular basis, it is at the subnational level where they form their views on their rights and responsibilities vis-à-vis the state (see Corbridge 2005). In African cities, where more than half of residents live in slums but a small middle-class and elite continues to grow (Resnick 2015; World Bank 2019a), municipal 
governments are grappling to forge social contracts with very diverse residents.

\section{Trust and Urban Informality: The Role of Reciprocity and Procedural Justice}

We examine specifically how the actions of city governments towards a critical segment of the urban poor-informal vendors - affect the latter's perceptions about the strength of the social contract. The strength of the social contract is often approximated by trust. In fact, trust is central to Locke's (1980) understanding of the social contract and is the cement that holds the reciprocal relationship together: "For all power given with trust for the attaining an end, being limited by that end, whenever the end is manifestly neglected or opposed, the trust must necessarily be forfeited and the power devolve into the hands of those who gave it" (section II, 149). Trust comes in at least three variants, particularized, generalized, and political trust. While particularized trust is limited to family, community, and neighborhood relationships, generalized trust represents a positive attitude towards individuals that one does not personally know (Uslaner 2002). Locke's notion of trust, and the one employed here, is political trust, which conveys confidence in a regime's institutions and procedures (Norris 2011).

Trust in state institutions implies that citizens have confidence that the state is reliable, impartial, and efficient. Such trust is viewed as critical for state legitimacy and a sign that citizens are willing to obey laws and other obligations: "The belief that government is trustworthy reflects the judgment that the authorities are motivated to deliver on their promises and do what is right for the people they service, seeking policies that truly benefit their societies" (Levi, Sacks, and Tyler 2009: 356). In other words, trust gives an indication of citizen confidence that their government will uphold its end of the social contract.

Informal vendors are a particularly important share of the urban economy in developing countries, and they constitute a major source of food security and employment for the poor in 
many African cities (Crush and Frayne 2011; Crush and Young 2019; Skinner 2019). We argue that their trust in local governments is shaped by their perceptions of the latter's ability to uphold the dynamics of reciprocity and procedural fairness that are central to the social contract. As shown elsewhere (Hardin 1993; Rothstein and Stolle 2008), these perceptions are based on personal experience and repeated interaction with relevant government institutions.

More specifically, while the state's capacity is a key driver of its ability to uphold the social contract, whether this engenders trust among citizens depends on their satisfaction and expectations. Rather than objective service delivery outcomes, trust appears to be tied to citizens' subjective assessments of performance (Mcloughlin 2015; Sacks 2011). In some instances, it is the gap between citizen expectations and performance of government that shapes citizen trust (Yang and Holzer 2006). For example, Brinkerhoff et al. (2016) find that rural Africans tend to have greater trust in government and more positive opinions of local and national officials than their urban counterparts even though they have worse access to services. They believe this is because urbanites have higher expectations from government. Expectations can be further predicated on how effectively citizens can attribute service provision to a particular state entity (Mcloughlin 2015).

Taxation is a major mechanism for linking expectations about reciprocity from the state; if you pay taxes for a service, it shapes your expectations that such a service should be delivered. Indeed, taxation traditionally has been viewed as central to upholding the social contract since it involves citizens contributing to public coffers in exchange for services (Prichard 2019). Although informal traders may not pay income taxes, they do pay a range of other fees that constitute an important source of revenue not only for local government operations but also for service provision (Meagher 2018; Moore, Prichard, and Feldstad 2018; Olken and Singhal 2011). 
To thrive and provide urban consumers with healthy foods, market traders and hawkers need access to clean water, drainage during the rainy season to avoid cholera, waste collection, toilets, electricity, and security. Attribution is usually high because vendors directly engage with revenue collectors and can closely observe whether the services they pay for, whether through city revenue collectors or fees to market organizations, actually materialize. For those who pay these fees, trust in local government presumably is lower when the expected services in exchange for those payments do not materialize (van den Boogaard, Prichard, and Jibao 2019; Fjeldstad 2004). More broadly, this amounts to the hypothesis below:

\section{H1: Trust in city authorities is lower when traders expect services that are not delivered}

Beyond satisfaction with services, a second potential driver of trust derives from Rawls' notion of procedural justice and particularly from perceptions of whether governments are competent and follow procedures that are viewed as fair, applied evenly, predictably, and transparently (Levi 1997; van der Meer 2017; Newton, Stolle, and Zmerli 2018). Especially in low capacity states, where service provision and law enforcement is uneven, assessments of procedural justice in government policies, even if they do not lead to ideal objective outcomes, are critical to generating trust (Sunshine and Tyler 2003). Political trust diminishes when citizens perceive a lack of fairness in procedural or distributive decisions, which can lead to questions about the state's impartiality (Tyler, Rasinski, and McGraw 1985). Such sentiments are likely to be especially pronounced when citizens feel they do not have a voice or an opportunity to influence the policy process (Levi, Sacks, and Tyler 2009). Again, repeated interactions with government institutions can shape these assessments and affect whether citizens are willing to accept decisions by authorities (Grimes 2016).

This is particularly relevant to African traders who are subject to multiple urban laws 
which, on paper, appear fair and equitable but in reality, disproportionately penalize the poor who cannot afford to comply (Glasser and Berrisford 2015). Specifically, they are often subjected to enforcement of public space, traffic safety, food safety, and land tenure laws that are erratically applied across time and space and often by very different types of local authorities. Attempts to make cities clean and attractive for investors and the middle-class can result in largescale eviction campaigns and every day, indiscriminate violence against street hawkers and marketeers (Resnick 2019; Skinner 2019; Smit 2016). By extension, those subjected to such harassment by city authorities would be expected to be less trusting because they either do not know what laws they are violating or recognize they are being treated differently than more affluent city residents.

\section{H2: Trust in city authorities is lower when traders are subjected to harassment by such authorities}

An alternative hypothesis is that political trust is a by-product of traders' degree of engagement in mediating institutions rather than directly caused by the actions of state authorities. Voluntary associations and networks can play a role in shaping individuals' levels of political trust (Freitag and Traunmüller 2009; Putnam 2000; Putnam, Leonardi, and Nanetti 1993). Voluntary associations may mediate between individual and institutional sources; those who participate in civic organizations engage in repeated interaction, learn the principles of cooperation, and the concept of the common good, which may improve their likelihood to be more trusting of state institutions (see Delhey and Newton 2003; Paxton and Ressler 2017). Market places in Africa, especially West Africa, often have market associations who engage with local governments over services and infrastructure. For instance, in Kumasi, King (2006) found that the Market Traders Association successfully reversed plans by the MMDA to increase fees by 300 percent. Informal workers' organizations more broadly can provide a "consultative 
arena" that foster democratic engagement (Chowdhury 2003; Heller 2000). This leads to the following hypothesis:

\section{H3: Trust levels are higher for traders participating in market associations}

In sum, the first two hypotheses are tied to reciprocity and procedural justice and related to whether they receive services for their taxes and fees and receive equal treatment under the law. The third, however, relies on how traders' other behaviors can mediate the lens through which they assess government authorities.

\section{Informal Food Trade in Ghanaian Cities}

Ghana is well-suited for exploring the above hypotheses for two key reasons. First, informal traders constitute the main residents in the country's cities. Ghana adopts the Informal Labor Organization (ILO) definition of informal, which refers to self-employment in informal enterprises as well as wage workers without legal or social protection who work for formal or informal firms, for households, or for no fixed employer (Ghana Statistical Service 2014). According to the 2014 Ghana Living Standards Survey (GLSS), the informal sector employs 88 percent of the working population, with a higher share for women than for men. This sector consists of small to medium scale enterprises comprised of producers, wholesale and retail traders, and service providers, and are largely self-employed farmers, artisans, and food traders, among others. Informal sector activities are more highly concentrated in urban areas, with 61.5 percent of urban labor force employed in the sector (Ghana Statistical Service 2014).

The importance of the informal economy has become more pronounced as the country has urbanized, with now more than half of the country's population living in urban areas (Ghana Statistical Service 2014). Between 1984-2013, Ghana's urban population growth was 4.4 percent annually and the urban population tripled from 4 to 14 million people (World Bank 2015). The 
levels of population pressure often expand during the day; according to the Accra Metro Assembly, the city's population swells from two to four million every day as workers commute in from the surrounding districts. ${ }^{5}$ As in most African cities, daily migrants travel long distances to work, they often eat most of their meals away from home out, and food from informal vendors is among the most affordable and accessible (FAO 2016). Based on calculations from the GLSS, the sub-share of vendors in the informal economy ranges from 10 percent of the population in Kumasi to a quarter of Tamale's (see Table 1).

Ghana's extensive decentralization constitutes a second reason for examining how the social contract is negotiated between cities and informal food vendors. Since 1993, the country's Local Government Act has allowed the metropolitan, municipal, and district assemblies (MMDAs) to make their own by-laws for the functions that were delegated to them under the Act. Due to their relatively high autonomy over regulating taxes, public space, and food safety, the focus on MMDAs, especially the cities, reveals important levels of variation that would be otherwise obscured by either just a national focus or one on the capital city alone.

Interviews with relevant policymakers in these cities revealed that there is a complex institutional architecture that governs the informal food sector, which is illustrated in Figure 1. The MMDAs are guided by national laws, particularly the Public Health Act of 2012, which is a criminal act that allows citizens to be prosecuted if they violate it. The department of agriculture provides oversight of fruits and vegetables. For meats, the Act gives oversight control to the national Food and Drugs Administration (FDA) and the veterinary department of the Ministry of Food and Agriculture (MoFA). The metro health department will work with the FDA to provide oversight of slaughterhouses and other infrastructure related to meats. Environmental health

\footnotetext{
${ }^{5}$ See https://ama.gov.gh/theassembly.php (accessed on May 29, 2019).
} 
officers engage in market surveillance of processed foods, focused on counterfeit, expired, and damaged merchandise as well as foods sitting on the ground. They can confiscate such goods, and the violators will be prosecuted by the MMDA courts. For instance, in Kumasi, a first offense requires payment of 12 Ghanaian cedis (GHS), and if a vendor fails to pay, she is jailed for between one to three months. ${ }^{6}$ The health department is also charged with providing traders with an annually renewable food handler certificate after the latter have undergone screening for a variety of diseases, including typhoid, cholera, dysentery, and tuberculosis, and adhere to hygiene food preparing and handling practices, including proper hand washing, covering their heads, and pinning their hair (Ackah, Gyamfi, Anim, et al. 2011; FAO 2016). ${ }^{7}$ The metro department of physical planning is responsible for the siting of markets and slaughterhouses. In addition to fees for food safety certificates, the revenue unit within the MMDA departments of finance oversee the collection of other fees from traders. These include the business operation permits, which are required for anyone intending to process or sell food (FAO 2016). Each MMDA has a fee fixing schedule that determines the amounts of such permits based on the market and business type and varies across cities. In Tamale Central Market, these range from 36 to 72 GHS per year for established stores while in Accra's 31 December market, they range from 15 to 31 GHS per month. ${ }^{8}$ Fees for those in open stalls will be lower while across all three cities, hawkers on the streets and pavements or from a table may pay anywhere from 0.50 to 1 GHS per day. Depending on the city, they will also issue temporary permits if an individual is trading from a structure that could be easily moved; such permits need to be renewed every three to six

\footnotetext{
${ }^{6}$ Interview with Environmental Health Officers in Kumasi.

${ }^{7}$ Interviews with Metro Public Health Directors in Accra and Tamale, and with Environmental Health Officers in Kumasi.

${ }^{8}$ Obtained from the Tamale and Accra fee fixing schedules provided by the MAs.
} 
months. ${ }^{9}$ The revenue garnered from license and public space fees for markets and street hawking is classified as "taxes on goods and services" in the Assembly budgets (Adamtey 2015).

\section{Figure 1: Institutional Landscape for Governing Informal Food Trade, Ghana}

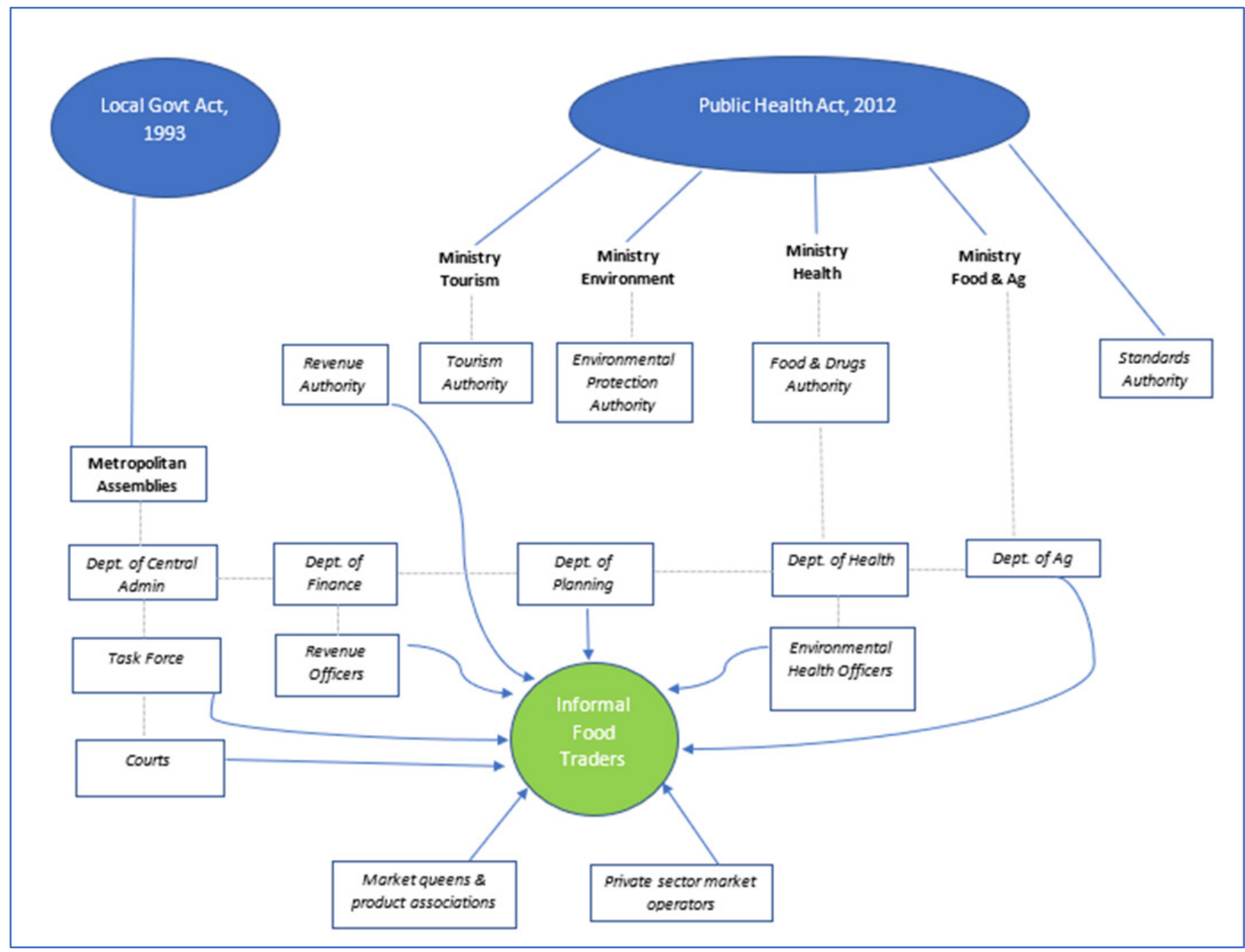

Source: Compiled by authors based on fieldwork interviews

\footnotetext{
${ }^{9}$ Interviews with Directors of Physical Planning, Accra and Tamale.
} 
Table 1 highlights the overall projected amounts of money obtained for this budget line by city. Despite similar population levels, Kumasi is more dependent on such taxes for its internally generated funds (IGF) than Accra, which has a more varied economic base. ${ }^{10}$ For the cities analyzed here, there are also Task Forces or Metro Guards under the metro department of security that enforce street hawking and "decongestion" by-laws, which are ostensibly aimed at ensuring traders are not impeding vehicle and pedestrian traffic. The central business districts tend be more targeted for decongestion campaigns due to the higher density of foot traffic. In Accra, for example, which updated its Street Hawkers by-laws in 2011, a redline policy was implemented in 2016 whereby pavements were painted with red lines to demarcate that traders could not sell past the line. ${ }^{11}$ Decongestion enforcement is financed out of the MMDAs' IGF, which means that there can be substantially different levels of enforcement depending on their socioeconomic resources. Table 1 below illustrates variations in the level of revenue across the three cities and the levels of IGF that constitute that revenue. Tamale clearly has lower capacity, in both financial and human resources, than the two larger cities.

\footnotetext{
${ }^{10}$ Revenue gained from rental fees is recorded as "property taxes" in the Assembly budget.

${ }^{11}$ Interview with Public Relations Officer, Accra. After traders began painting their own red lines, the city switched to painting yellow lines.
} 
Table 1: Overview of Staff, Financing, and Population for Ghanaian Cities

\begin{tabular}{|l|c|c|c|}
\hline $\begin{array}{l}\text { Financing \& } \\
\text { Staffing (latest year } \\
\text { available) }\end{array}$ & Accra & Kumasi & Tamale \\
\hline Total revenue (GHS) & $3,151,613,612$ & $107,376,398$ & $25,225,437$ \\
\hline $\begin{array}{l}\text { Total IGF in revenue } \\
\text { (GHS) }\end{array}$ & $54,858,185$ & $36,137,000$ & $2,039,459$ \\
\hline $\begin{array}{l}\text { Revenue from taxes } \\
\text { on goods and services } \\
\text { (GHS) }\end{array}$ & $22,662,985$ & $23,519,000$ & 767,650 \\
\hline $\begin{array}{l}\text { Share of taxes on } \\
\text { goods and services in } \\
\text { IGF }\end{array}$ & 41.3 & 65.1 & 37.6 \\
\hline $\begin{array}{l}\text { Number of members } \\
\text { of Task Force/Metro } \\
\text { Guards }\end{array}$ & 200 & 95 & 40 \\
\hline $\begin{array}{l}\text { Number of } \\
\text { environmental health } \\
\text { officers }\end{array}$ & 349 & 153 & 79 \\
\hline Population of city & $2,070,463$ & $2,035,064$ & 371,351 \\
\hline $\begin{array}{l}\text { Number of informal } \\
\text { vendors }\end{array}$ & 237,741 & 195,577 & 94,443 \\
\hline $\begin{array}{l}\text { Informal vendors as a } \\
\text { share of the } \\
\text { population }\end{array}$ & 11.5 & 10.0 & 25.4 \\
\hline
\end{tabular}

Source: Fieldwork interviews, March 2018; Population projections based on the 2010 Census and available at: http://www.citypopulation.de/Ghana-Cities.html. Data on Tamale's Task force from https://starrfm.com.gh/2017/05/tamale-chief-assaulted-over-decongestion-exercise (accessed October 2019). Fiscal and staffing data is available from the composite budgets for all three cities, for most recent year where data is available and can be accessed from the Ministry of Finances' Fiscal Decentralization Unit at:

https://www.mofep.gov.gh/publications/composite-budget. Data on vendors is from GSS (2014).

\section{Descriptive Statistics of Survey Sample}

To examine levels and determinants of trust in Ghana's local governments, a survey was conducted with 1,214 food traders across 16 markets in the three cities. As seen in Figure 2, the markets were chosen to be distributed across different locations in the city to capture the experiences of those in central business districts versus informal settlements. To be proportional to size of population and numbers of markets, fewer markets were sampled in Tamale (4) than in Accra and Kumasi (6 each). 
Figure 2: Map of Market Locations in Accra, Kumasi, and Tamale
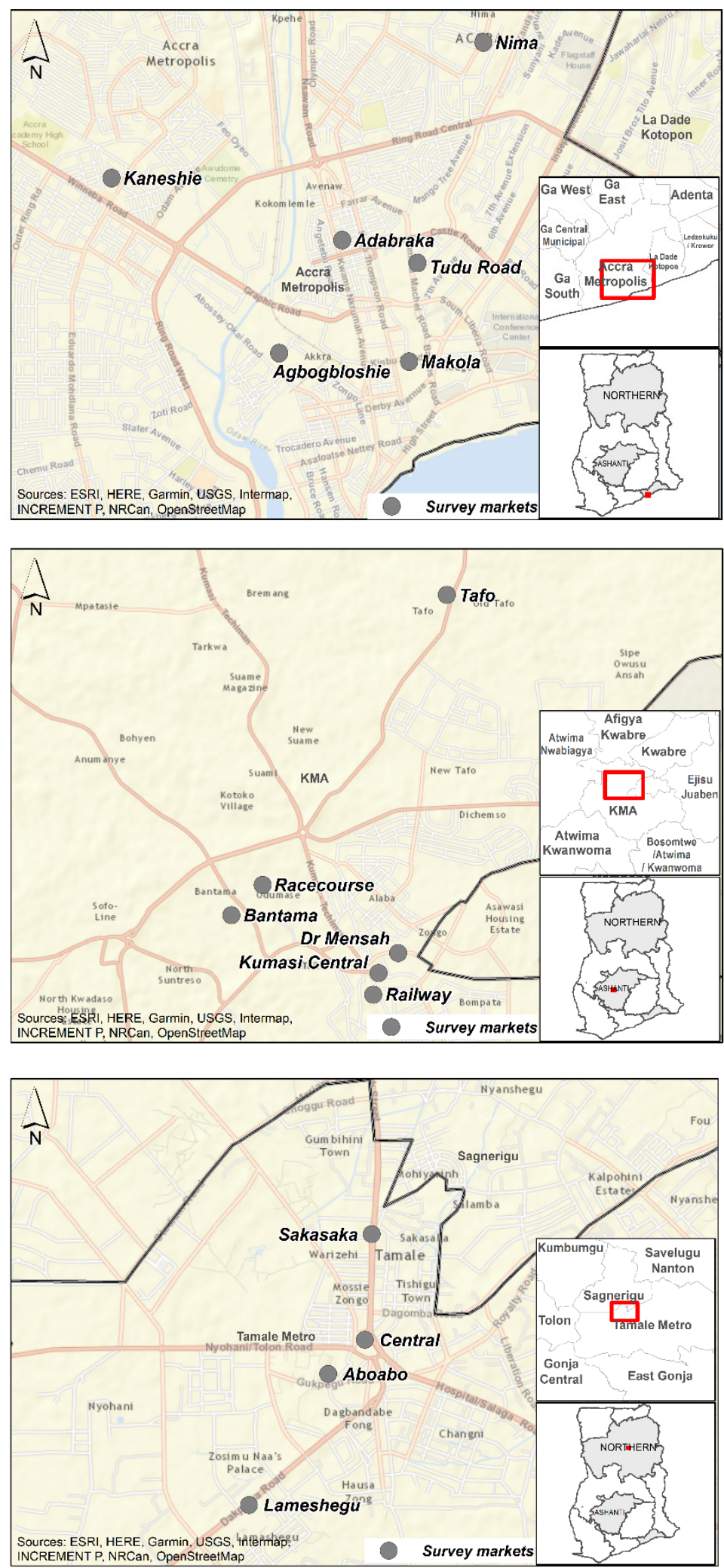
Surveying informal traders can be much more complex than a typical household survey due to the density of respondents. The approach for choosing respondents within the markets should be methodical while still reflecting a degree of randomness so that respondents do not feel that they were inappropriately targeted. There were two objectives to the sampling approach: 1) include only food traders in the survey and 2) ensure an equal mixture of respondents located properly within a market and those selling outside a market on the pavement or streets. This second objective was motivated by the fact that those outside of markets are potentially more vulnerable to harassment by government authorities since they operate on public sidewalks and streets. They also pay fewer taxes to the MMDAs but have less access to the services within the markets. In addition, traders inside and outside the markets can have a contentious relationship since the former believe the latter have greater proximity to customers but are not required to pay as much to authorities. ${ }^{12}$

Every third food vendor was selected based on a random walk approach that ensured that even in market settings where there were multiple rows of vendors along the path or street, each one had a relatively equal chance of being selected rather than just those who were most accessible in the front row. To be eligible to be surveyed, the respondent had to have been at least 18 years old. There was no attempt at gender parity since that is not reflective of the broader population of food vendors in Ghana; except for meat, women disproportionately control food trade (Awo 2012; Baah-Ennumh and Adom-Asamoah 2012).

Tables 2 provides profiles of the traders in the sample. Reflecting the lack of gender parity in the survey sampling, women comprise high shares of the sample and equivalent to those found in other studies of informal food trade in Ghanaian cities (see FAO 2016). In terms of

\footnotetext{
${ }^{12}$ Interview with Ghana country coordinator for the Women in Informal Employment: Globalizing and Organizing (WIEGO), May 2017.
} 
ethnicity, the distribution of traders is equivalent to the ethno-linguistic profile in their respective cities. For example, the Akan and Mole-Dagbani are the dominant communities in Kumasi and Tamale, respectively. Accra is a more diverse city, with a higher share of migrants from outside the MMDA, but the indigenous Ga still comprise a plurality of the vendors. Based on a socioeconomic index that captures whether the respondent's household has access to up to 12 different services and assets, there is relatively little difference across cities. In Accra and Kumasi, a large proportion of vendors have at least some secondary education, but almost 47 percent of respondents in Tamale have not had any schooling.

Associational membership is objectively low across all three cities but relatively higher in Accra. Product associations play an important role, especially in the southern part of Ghana. Many fresh food traders are organized into associations based on the commodity that they sell. According to Awo (2012), such associations will include itinerant traders, bulk buyers, and retailers and often controlled by queen mothers who have a large degree of control over the markets. The queen mother for each commodity will have an office located in the market of each region's capital city. The associations and commodity queens resolve disputes among traders, manage credit relations, provide assistance during crisis events, such as a family death, and acquire market information (Clark 2018; Lyon 2003). However, Brown et al.(2010) note that many traders decide not to join these because the membership fees are too high or they prefer to deal directly with market and municipal authorities. Moreover, the chairwoman of the Informal Hawkers and Vendors Association of Ghana (IHVAG) explained that it was often impossible for fresh food vendors to leave their goods unattended to go to associational meetings. ${ }^{13}$

\footnotetext{
${ }^{13}$ Interview with IHVAG chairwoman, May 2017, Accra's Makola Market.
} 
Table 2: Descriptive Statistics, Means

\begin{tabular}{|c|c|c|c|c|}
\hline Variable & Accra & Kumasi & Tamale & Total \\
\hline \multicolumn{5}{|l|}{ Full Sample of Traders } \\
\hline Female, $\%$ & 94.5 & 90.9 & 84.1 & 90.5 \\
\hline \multicolumn{5}{|l|}{ Ethnic community cultural, group, or tribe, $\%$} \\
\hline Akan & 32.4 & 81.1 & 3.7 & 43.7 \\
\hline Ga-Dangme & 35.0 & 0.7 & 0.0 & 13.3 \\
\hline Ewe & 18.9 & 1.1 & 2.7 & 8.2 \\
\hline Guan & 0.7 & 0.7 & 2.3 & 1.1 \\
\hline Gurma & 0.7 & 0.2 & 0.0 & 0.3 \\
\hline Mole-Dagbani & 7.3 & 9.8 & 86.7 & 27.9 \\
\hline Grusi & 0.2 & 1.1 & 0.0 & 0.5 \\
\hline Mande & 0.4 & 0.9 & 0.0 & 0.5 \\
\hline All other tribes & 3.5 & 4.1 & 4.0 & 3.9 \\
\hline \multicolumn{5}{|l|}{ Age groups } \\
\hline $18-24$ & 6.4 & 3.1 & 6.6 & 5.2 \\
\hline $25-34$ & 22.0 & 23.1 & 26.9 & 23.6 \\
\hline $35-44$ & 31.9 & 33.1 & 24.6 & 30.6 \\
\hline $45-54$ & 24.2 & 25.9 & 20.6 & 24.0 \\
\hline $55-64$ & 9.9 & 9.4 & 7.6 & 9.1 \\
\hline 65 or older & 4.0 & 3.3 & 3.3 & 3.5 \\
\hline Don't know or refused to answer & 1.4 & 2.2 & 10.2 & 4.0 \\
\hline \multicolumn{5}{|l|}{ Education, \% } \\
\hline No school & 20.7 & 18.3 & 46.5 & 26.2 \\
\hline Some primary & 11.7 & 19.2 & 16.9 & 15.8 \\
\hline Primary completed & 10.1 & 19.4 & 7.6 & 13.0 \\
\hline Some secondary & 36.1 & 27.0 & 18.9 & 28.4 \\
\hline Secondary completed & 17.2 & 12.6 & 5.7 & 12.6 \\
\hline Post-secondary qualification & 4.2 & 2.8 & 4.0 & 3.6 \\
\hline Migrant to MMDA (\%) & 57.3 & 43.6 & 20.3 & 42.9 \\
\hline Socioeconomic index (0 to 12$)^{\mathrm{a}}$ & 7.4 & 7.1 & 7.0 & 7.2 \\
\hline $\begin{array}{l}\text { Member of any association or organization } \\
\text { related to job }(\%)\end{array}$ & 18.7 & 9.8 & 5.0 & 11.9 \\
\hline Owner of stall $(\%)$ & 13.4 & 13.5 & 23.9 & 16.1 \\
\hline $\begin{array}{l}\text { Experienced harassment over their lifetime } \\
(\%)\end{array}$ & 25.1 & 41.4 & 26.3 & 31.6 \\
\hline Experienced harassment over last year (\%) & 11.7 & 23.1 & 13.6 & 16.5 \\
\hline $\begin{array}{l}\text { Pay required business operating fees to the } \\
\text { Assembly (\%) }\end{array}$ & 85.0 & 89.8 & 36.2 & 74.7 \\
\hline $\begin{array}{l}\text { Identify services received for payments to } \\
\text { MMDA }(\%)\end{array}$ & 8.2 & 15.7 & 8.6 & 11.1 \\
\hline $\begin{array}{l}\text { Government official you come into contact } \\
\text { with most often in month: MMDA revenue } \\
\text { collector }\end{array}$ & 88.5 & 59.0 & 35.2 & 64.1 \\
\hline
\end{tabular}




\begin{tabular}{|l|c|c|c|c|}
\hline $\begin{array}{l}\text { Government official you come into contact } \\
\text { with most often in month: Task Force }\end{array}$ & 1.3 & 14.6 & 13.0 & 9.2 \\
\hline $\begin{array}{l}\text { Average frequency of accessing news per } \\
\text { week ( } 0=\text { never, } 4=\text { every day) }\end{array}$ & 3.2 & 3.2 & 3.2 & 3.2 \\
\hline$N$ & 453 & 456 & 300 & 1209 \\
\hline
\end{tabular}

Source: International Food Policy Research Institute (2020)

Notes: ${ }^{a}$ This index is measured according to whether a household has access or not to the following twelve assets and services: radio, television, bicycle, vehicle (car or motorbike), refrigerator, mobile phone, computer, electric fan, electric/gas stove, piped water, flush toilet, and garbage collection.

Table 2 further highlights whether they have experienced a form of harassment by authorities from their MMDA during both their entire time as a trader and also during the 12 months previous to the time of the survey. Such harassment encompasses three forms of behaviors. The first is confiscation of merchandise by authorities that can occur when traders sell unsafe or expired foodstuffs, or if they are selling without a permit and have not paid their required fees to the MMDA. The second is forcible re-location, which can occur when traders are selling in a market targeted for upgrading, hawking in public spaces that are proscribed by the by-laws, or vending in an unsafe locations, such as near railroad tracks or under electricity pylons. The third, which was the least common for the sample, was being arrested for refusing to pay a fine levied for contravening by-laws or being a repeat offender. There are certainly other forms of harassment that traders encounter, including requests for bribes from authorities to avoid confiscation of goods and sexual exploitation to avoid paying fees (Osei-Boateng 2019). However, due to the difficulty of measuring these types of exchanges through a survey instrument, they were not included. This implies that the levels of harassment reported here are most likely understated.

Experiences with these collective forms of harassment is highest in Kumasi. Indeed, 41 percent of the traders in Kumasi had experienced harassment over their lifetime, and 23 percent had so just in the previous 12 months. This resonates with a great deal of secondary literature 
that emphasizes the particularly draconian approach to decongestion that successive mayors of Kumasi have pursued, especially with those trading on pavements and streets. Clark (2013:29) observes that "Government crackdowns on street vendors in Kumasi, Ghana, have been repeated so often that their occurrence requires less explanation than their absence." The Guards were established back in 1962, but they did not start engaging in decongesting traders until Akwasi Agyemang became mayor in $1976 .{ }^{14}$ During his 23 years in office, he gained the name "Terror of Kumasi" with his particularly harsh treatment of street hawkers and market women (ObengOdoom 2011). Today, the Guards patrol daily from 6:30am to 6pm and divide into five or six groups, which have access to four vehicles between them. ${ }^{15}$ The Guards retain a warehouse with seized goods that can be retrieved by traders if they pay a fine and sign an "undertaking" pledging not to return to where they were arrested. ${ }^{16}$

However, the other cities are not immune to government crackdowns. Accra has also had a large share of decongestion campaigns (Bob-Milliar and Obeng-Odoom 2011; Gillespie 2016; Steel, Ujoranyi, and Owusu 2014), with more than 16 between 2000 and 2016 (Resnick 2019). They also have a special court that was established to deal with offenders of its by-laws, who have to pay a fine or spend up to three months in prison, which can be commuted to communal labor (GTUC 2012). The campaigns though tend to be more episodic and focused on particular areas of the city at a certain time. ${ }^{17}$ Tamale also conducts these occasionally; the mayor had initiated an effort to set up a Sunday market for street traders. ${ }^{18}$ Due to relatively low revenue, its Task Force is comparatively smaller than Accra's and Kumasi's (see Table 1) and most times,

\footnotetext{
${ }^{14}$ Interview the Head of the Kumasi Metro Guards.

15 Ibid.

16 Ibid.

${ }^{17}$ Interview with AMA's Public Relations Officer.

${ }^{18}$ Interviews with Metro Coordinating Director and Head of Tamale Task Force.
} 
they only remove vendors if they receive a complaint. ${ }^{19}$

These experiences with harassment are typically interpreted as being unjust. As one itinerant hawker, aged 55-64 in Accra noted, "I was just there, and a police officer came to arrest me for no reason." Complaints about procedural fairness were most pronounced in Kumasi, with illustrative quotes including the following: "My things were thrown away like some rubbish by the task force," "I left this present trading place for my daughter while I traveled and when I came back, they [the task force] had come to destroy my table and destroy the pot the koko was in,"20 "KMA [Kumasi Metropolitan Assembly] should stop seizing our goods because that is what we are using to take care of our kids," and "KMA Task Force is always on our neck to move from our place of work."21

Another difference among the three cities is that traders are more likely to pay the required fees to MMDA in Accra and Kumasi than in Tamale. This largely supports the trend in Table 1 that internally-generated revenue garnered from traders through taxes on goods and services is much lower in Tamale. By contrast, among the few who do pay their fees to the Assembly, those in Kumasi have a slightly higher share on average who can attribute some service they receive in return for those payments. But while almost the same share of traders pay fees to their MMDAs in Accra and Kumasi, traders in Accra report a lower ability, on average, of attributing their payments to any benefit from their Assembly. This affirms a study by Adamtey (2015), which uncovered that only 10 percent of the revenue collected from traders in Accra was re-invested into the markets.

\footnotetext{
${ }^{19}$ Interview with Tamale Metro Planning Director.

${ }^{20}$ Koko is a form of millet porridge.

${ }^{21}$ Survey respondents A03404, K07116, A04304, K07616, K06116, respectively.
} 
Figure 3 examines the levels of trust that respondents have in their MMDAs. Specifically, respondents were asked: "How much do you trust your MMDA?" They could give a response along a Likert scale of "not at all, a little, and a lot," and the responses in Figure 3 aggregate the latter two categories. This is the most common way that trust is measured in much of the literature, which draws on either World Values Surveys or the Afrobarometer, Latinobarometer, and Arabarometer surveys (Brinkerhoff, Wetterberg, and Wibbels 2016; Inglehart 2003; Mattes and Moreno 2018; Sacks 2011). Notably, the levels of trust in MMDAs varies across the three cities, and the non-overlapping confidence intervals indicating that this variation is statistically significant.

Figure 3: Variations in Trust across Ghanaian Cities

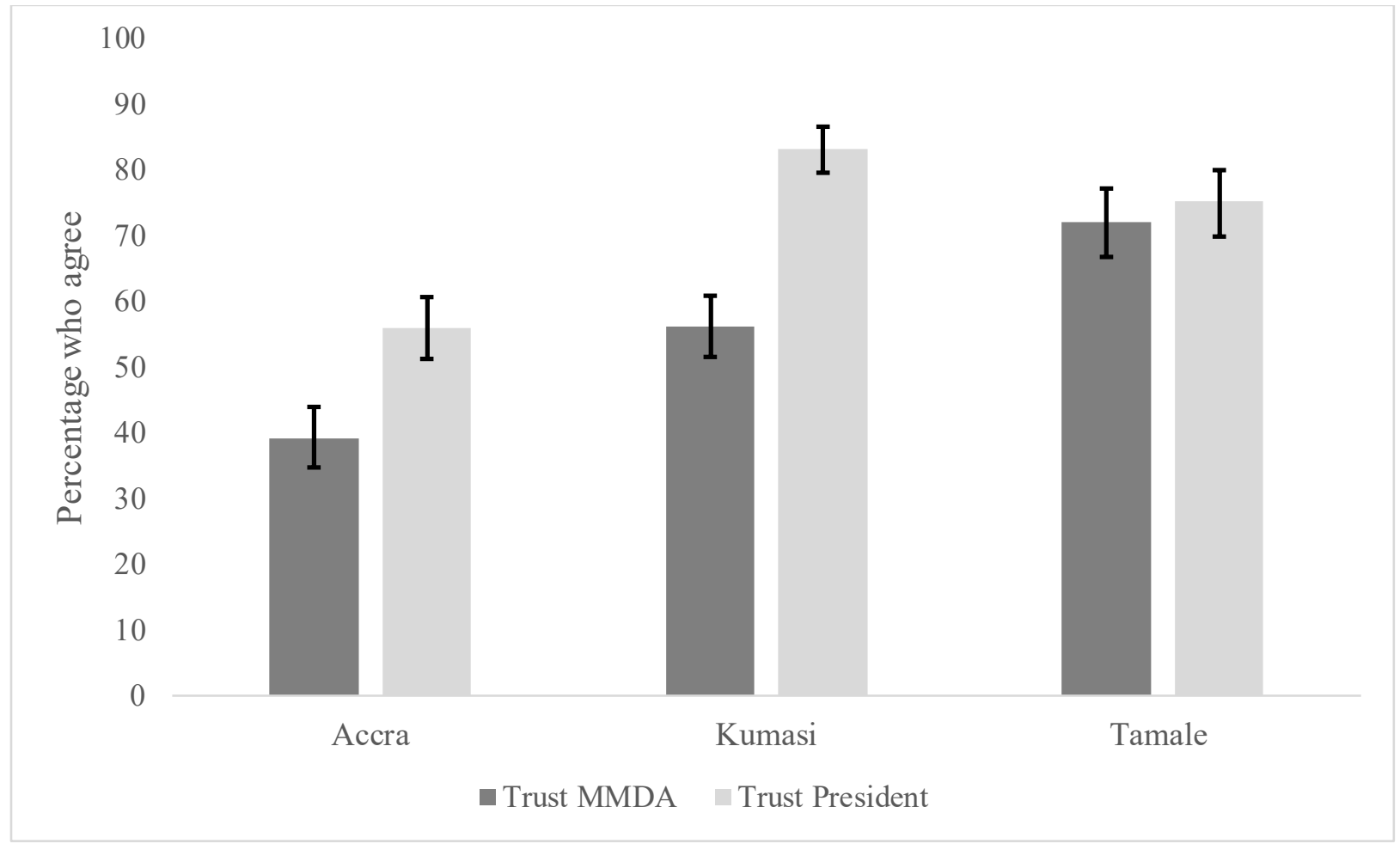

Source: International Food Policy Research Institute (2020)

Notes: Vertical bars indicate 95 percent confidence intervals. $\mathrm{N}=1,209$.

Importantly, this metric can fail to capture the fact that trust is domain-specific and varies 
by task (Cook, Hardin, and Levi 2005). Moreover, citizens often are likely to mistakenly transfer their experience with any government institution to their assessments of political trust (Cleary and Stokes 2009). Nevertheless, given the central role that local assemblies play in enforcing bylaws and providing services to market traders in the Ghanaian context, it appears to be a more valid measure than if other types of actions—-such as energy or foreign policy—were being ascribed to it. Furthermore, by looking at trust in the president, this differentiation becomes apparent; in Accra and Kumasi, levels of trust in the president were significantly higher than they were for the MMDA, confirming the fact that respondents drew a distinction between government entities.

\section{Impacts on Trust}

To explain the above variation in political trust among informal traders across these three cities, a binomial logit analysis was conducted to determine the likelihood that respondents claim they trust their MMDA "a lot or a little" instead of not at all. A model capturing the hypotheses discussed earlier was run for five different samples of traders. To test the reciprocity hypothesis, we include whether respondents paid their required fees to their respective MMDA. This fee payment refers to the business operating permits discussed earlier, which vary by stall type, market, and city and are intended to improve water, sewage, electricity, sanitation, and security services in the markets. Those who have paid presumably are more likely to have stronger expectations than those who do not pay about their MMDA's ability to deliver services. Moreover, those who are (dis)satisfied with service provision due to their fee payments would likely be more (dis)trusting of the MMDA. As a result, we incorporate an interaction term for those who claim to have paid their requisite fees and can identify what exactly they believe they receive in return for such payments. To examine the effects of procedural justice, we include 
whether respondents experienced any type of harassment by their MMDA in the 12 months prior to the survey. This dummy variable reflects whether a trader experienced any of the following three types of targeting by authorities: seizure of merchandise, forcible relocation, and arrest for violating trading laws.

Since a one-time negative experience with harassment may not sufficiently affect perceptions of trust, we also examine whether and which types of government officials a respondent engages with the most during the course of a typical month. We code into a dummy variable those who identify an Assembly bureaucrat, including a revenue collector, health inspector, task force member, or the police, versus no interaction with the MMDA at all. By looking specifically at engagement with MMDA officials, we have greater confidence that we are controlling for local level experiences.

To determine the role that mediating institutions play in shaping trust of traders, a dummy variable is included to account for whether a respondent is a member of a trader's association. We also explore the role of information about local government in the levels of political trust, proxied by the frequency at which respondents access the news-from either radio, television, newspaper, or online — and the resulting index ranges from 0 ("never") to 4 ("everyday").

Traditional demographic controls were also included. For instance, research in industrialized countries has found that distrust is higher among those who are less educated (Putnam 2000). Others, however, find that those who are more educated tend to be more critical of state institutions because they may have higher expectations of how the state should perform (Inglehart 2003; Sanchez and Senderowitsch 2012). In general, education not only allows citizens to gain factual information about government performance but also leads to higher 
expectations of democratic norms (Hakverdian and Mayne 2012). Consequently, we include a dummy variable for whether a respondent has completed secondary education or beyond. ${ }^{22}$ In addition, we include whether a respondent is female and to which age group they belong. ${ }^{23}$

Table 3 presents the findings for the five samples. The first includes all traders aggregated together while the subsequent one targets traders who are located inside a market, rather than trading outside on the streets and pavement. Traders inside markets comprised half of all respondents. They are less exposed to harassment because they are more likely to be in established stalls and stores. However, they typically pay more in fees and since the opportunity cost of moving to another location is higher than if they were on the street, they likely have higher expectations that services should be delivered for those payments. ${ }^{24}$ The last three models isolate the samples for each city. While including the cities as dummy variables would have shown the significance between these cities and levels of trust, it would not have highlighted the degree to which the hypotheses on drivers of trust could vary across cities. A multilevel model was not possible since the number of cities - three-is well below the sample size threshold for such a technique (Schoeneberger 2016). To address other potential heteroskedasticity issues, standard errors are clustered at the market level using bootstrapping to account for the relatively low number of markets per city (see Huang 2018).

\footnotetext{
${ }^{22}$ Other controls, such as whether a trader was a migrant to the city and ethnicity, were found to have no effect on the subsequent results and for space constraints, were excluded from the subsequent results. However, the results can be provided upon request.

${ }^{23}$ Since pre-tests revealed a reluctance of respondents to share their actual age, the survey relied on age groups.

${ }^{24}$ Specifically, 21 percent of those inside markets own their store, stall, or kiosk while only 10 percent outside of the markets do. Moreover, while only eight percent of those inside the markets experienced harassment over the last year, 25 percent outside did.
} 


\section{Findings}

The table indicates that for the full sample of traders, and particularly for inside traders, simply paying taxes to the MMDA is associated with a reduction in trust of that MMDA. However, across all five samples, paying the requisite fees to the MMDA and being able to identify a benefit in return enhances trust in the relevant local government. As expected, this is substantively most significant among those inside the markets but particularly in Accra. Based on predictive probabilities calculated from Table 3 , trust increases from 35 to $69-$ a difference of 34 percent - for a trader in Accra who attributes a benefit to their fee payments compared to someone in the capital city who does not. As seen in Figure 4, the equivalent differences in margins are 24 and 19 percent in Kumasi and Tamale, respectively. Taken together, these results imply that paying taxes alone can undermine trust when there is no perceived benefit in return.

While harassment is associated with a decline in trust for the full sample, this pattern is most pronounced in Kumasi. In fact, based on predicted probabilities, someone who has been harassed in the last year is only 39 percent likely to trust the Kumasi MMDA while someone who has not has a 61 probability. This is not surprising given the city's history, and the fact that a quarter of its traders reported harassment just in the last year (see Table 2).

The most important demographic control is education. More educated respondents are less trusting of their Assemblies. Since most traders in Accra have at least completed their secondary education, while only a minority have done so in the other two cities, the statistical impact of education is less pronounced in the capital. Interestingly, news access has a more positive relationship, especially in Accra. Although only speculative, this may be due to learning about other achievements of the local government that extend beyond the arena of informal trade. 
Figure 4: Trust in MMDA, Predictive Probabilities
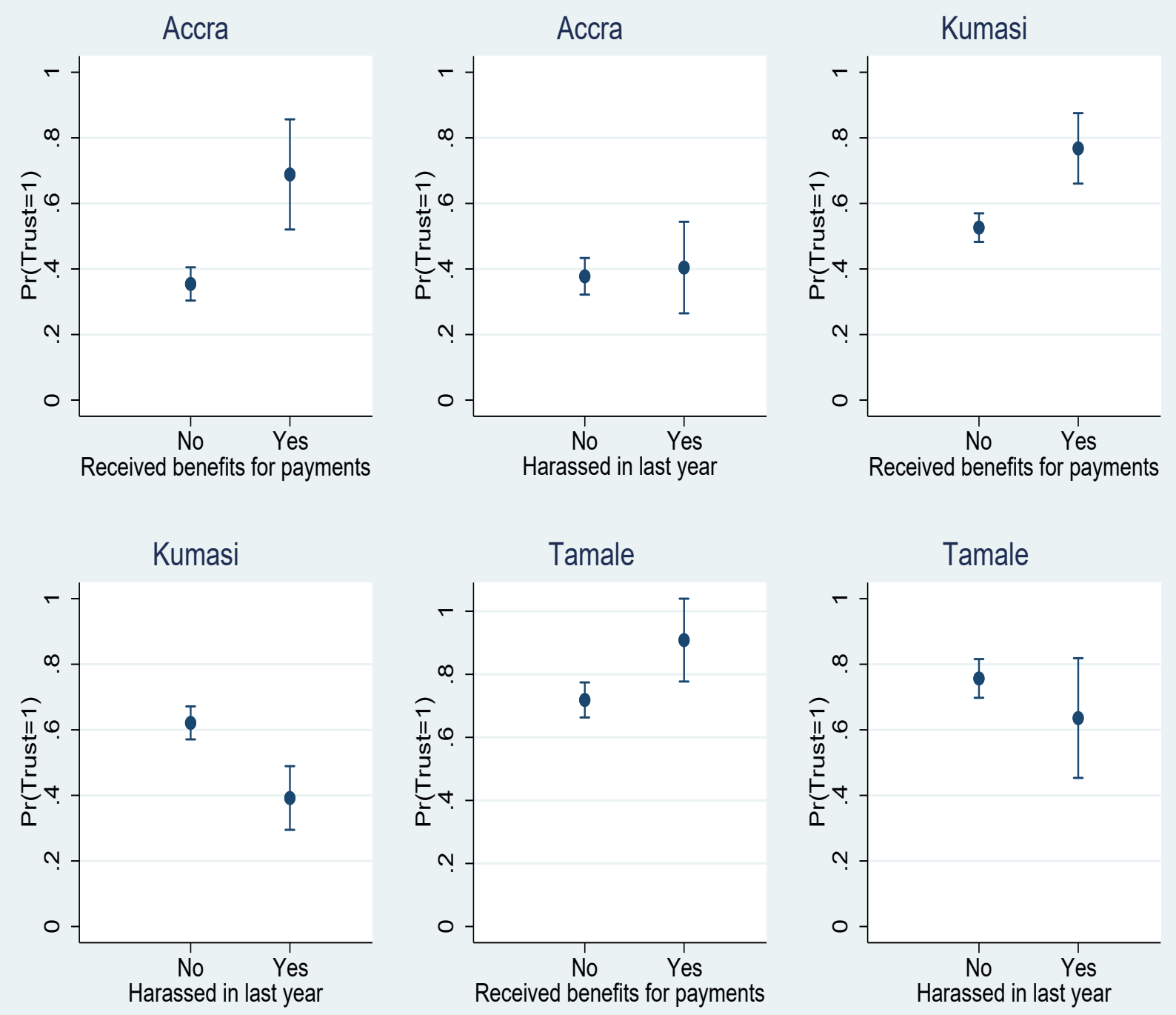

Notes: The dependent variable is the probability of trust in MMDA when all other variables are held at their means. The dots represent the probability and the lines represent the confidence intervals at 95 percent.

Participation in a traders' union generates some surprising results. Membership in a traders' association translates into lower political trust, particularly in Accra and among inside traders. This suggests that the way in which the union mediates relationships with the local government is deserving of more attention. In Accra, where union membership is largest, such 
associations have sometimes come into conflict with local authorities over governance in the markets (Bob-Milliar and Obeng-Odoom 2011; Obeng-Odoom 2011). As noted by Uslaner (2002), associations may improve particularized trust in those who are "like us" but may not necessarily improve political trust. 
Table 3: Logit Analysis of Drivers of Trust in Local Government

\begin{tabular}{|c|c|c|c|c|c|}
\hline Variable & Full sample & $\begin{array}{l}\text { Inside } \\
\text { Traders }\end{array}$ & Accra & Kumasi & Tamale \\
\hline Regularly pay trading fees to MMDA & $\begin{array}{l}-0.419 * \\
(0.19)\end{array}$ & $\begin{array}{l}-0.615^{* *} \\
(0.22)\end{array}$ & $\begin{array}{l}-0.252 \\
(0.33)\end{array}$ & $\begin{array}{l}-0.447 \\
(0.84)\end{array}$ & $\begin{array}{l}0.146 \\
(0.30)\end{array}$ \\
\hline Receive benefits for payments to MMDA & $\begin{array}{l}1.268^{* * * *} \\
(0.20)\end{array}$ & $\begin{array}{l}1.403 * * * \\
(0.33)\end{array}$ & $\begin{array}{l}1.386^{* * * *} \\
(0.48)\end{array}$ & $\begin{array}{l}1.091 * * * \\
(0.33)\end{array}$ & $\begin{array}{l}1.358 * \\
(0.68)\end{array}$ \\
\hline Experienced harassment by MMDA over last year & $\begin{array}{l}-0.450+ \\
(0.25)\end{array}$ & $\begin{array}{l}-0.790 \\
(0.61)\end{array}$ & $\begin{array}{l}0.106 \\
(0.36)\end{array}$ & $\begin{array}{l}-0.933 * \\
(0.45)\end{array}$ & $\begin{array}{l}-0.577 \\
(0.39)\end{array}$ \\
\hline Engage with an MMDA employee on a monthly basis & $\begin{array}{l}-0.493^{*} \\
(0.23)\end{array}$ & $\begin{array}{l}-0.195 \\
(0.33)\end{array}$ & $\begin{array}{l}0.177 \\
(0.50)\end{array}$ & $\begin{array}{l}-0.325 \\
(0.41)\end{array}$ & $\begin{array}{l}-0.225 \\
(0.31)\end{array}$ \\
\hline Frequency of news access ( 0 to 4$)$ & $\begin{array}{l}0.176^{*} \\
(0.08)\end{array}$ & $\begin{array}{l}0.190 \\
(0.16)\end{array}$ & $\begin{array}{l}0.353^{* * *} \\
(0.11)\end{array}$ & $\begin{array}{l}-0.113 \\
(0.20)\end{array}$ & $\begin{array}{l}0.053 \\
(0.05)\end{array}$ \\
\hline Participate in a traders' union & $\begin{array}{l}-0.639^{*} \\
(0.32)\end{array}$ & $\begin{array}{l}-0.853^{*} \\
(0.40)\end{array}$ & $\begin{array}{l}-0.724^{*} \\
(0.32)\end{array}$ & $\begin{array}{l}0.007 \\
(0.20)\end{array}$ & $\begin{array}{l}0.157 \\
(1.10)\end{array}$ \\
\hline Ages 18-34 & $\begin{array}{l}0.206 \\
(0.25)\end{array}$ & $\begin{array}{l}0.267 \\
(0.30)\end{array}$ & $\begin{array}{l}1.040^{* * * *} \\
(0.27)\end{array}$ & $\begin{array}{l}0.372 \\
(0.43)\end{array}$ & $\begin{array}{l}-0.832 \\
(4.39)\end{array}$ \\
\hline Ages 35-54 & $\begin{array}{l}0.083 \\
(0.17)\end{array}$ & $\begin{array}{l}0.113 \\
(0.23)\end{array}$ & $\begin{array}{l}0.709^{*} \\
(0.33)\end{array}$ & $\begin{array}{l}0.326 \\
(0.29)\end{array}$ & $\begin{array}{l}-0.768 \\
(4.47)\end{array}$ \\
\hline Completed secondary education or higher & $\begin{array}{l}-0.689 * * * \\
(0.16)\end{array}$ & $\begin{array}{l}-0.700^{* *} \\
(0.26)\end{array}$ & $\begin{array}{l}-0.284 \\
(0.221)\end{array}$ & $\begin{array}{l}-0.664 * \\
(0.30)\end{array}$ & $\begin{array}{l}-0.945 * * * \\
(0.13)\end{array}$ \\
\hline Female & $\begin{array}{l}0.082 \\
(0.24)\end{array}$ & $\begin{array}{l}0.003 \\
(0.28)\end{array}$ & $\begin{array}{l}0.450 \\
(0.43)\end{array}$ & $\begin{array}{l}0.510 \\
(0.38)\end{array}$ & $\begin{array}{l}0.082 \\
(0.38)\end{array}$ \\
\hline$N$ & 1209 & 601 & 453 & 456 & 300 \\
\hline
\end{tabular}

Cluster bootstrapped standard errors in parentheses

${ }^{+} p<0.10,{ }^{*} p<0.05,{ }^{* *} p<0.01,{ }^{* * *} p<0.001$ 
An alternative explanation for these results focuses on the broader political system in which citizens are embedded. The partisanship hypothesis suggests that citizens take cognitive shortcuts and are more likely to trust government institutions when their preferred party is in office. Research on national level trust in developed countries frequently shows that trust is often higher for those who are co-partisans of the ruling regime (Frye and Borisova 2019;

Gershtenson, Ladewig, and Plane 2006). Scholarship in the US suggests that such an association is equally feasible at the subnational level. For instance, cities governed by elected mayors are viewed as more responsive to citizens while those under an appointed manager are believed to be more efficient and better performers (Rahn and Rudolph 2005). Likewise, cities that allow partisan elections can be more prone to polarization and therefore undermine trust (Copus, Wingfield, Steyvers, et al. 2012; Rahn and Rudolph 2005).

However, in Ghana, such a hypothesis is less relevant since the MMDAs are governed by appointed rather than elected executives, and elections for other MMDA members are legally non-partisan. Still, some suggest that local politicians can find clandestine ways to showcase their party leanings (Williams 2017). Yet, even though respondents were not asked about their political affinities, we are relatively confident that partisanship is not driving differential levels of trust in city governments. At the time of the study, the ruling party was the New Patriotic Party, which historically has won large shares of votes in Kumasi, including in the 2016 elections. The opposition party, the National Democratic Congress, traditionally gains large shares of support in Tamale with both parties competitive in Accra. If partisanship of the president, who appoints the mayor (known as the Metropolitan Chief Executive), was a major driver of trust in the MMDA, then we would have expected trust to be highest in Kumasi and lowest in Tamale. However, we found the opposite trend. 


\section{Empirical Implications of Trust}

Does trust in local government matter? Importantly, some skepticism of political institutions can be healthy as it prevents governments from being too complacent, ensures citizens stay engaged, and avoids unquestioning support for political leaders (Mishler and Rose 1997). But, there is equally research that indicates that low political trust can result in a host of negative outcomes, including a greater acceptance of breaking the law (Marien and Hooghe 2011) and lower perceptions of state legitimacy (Hetherington 1998; Levi, Sacks, and Tyler 2009).

As Table 4 shows, an absence of trust can undermine the willingness of citizens to uphold their side of the social contract. Specifically, the sub-sample of food traders who work inside a market were asked to identify one key service in their market that they wanted to be improved. Street traders were excluded since it is those based in the markets who have greater access to such services. Drainage, garbage collection, and toilets were among the top priority areas, identified by 21,17 , and 8 percent of the respondents, respectively. They were then asked whether they would pay a little bit more to their MMDA each month for improving that priority area. Those who expressed trust in their MMDA were associated with a higher likelihood of agreeing to paying more, even when controlling for the level of those services already in their market, their own socioeconomic status, and whether they are the owner or not of their stall, rather than a renter or employee. This suggests that raising revenue for service provision, and thereby reinforcing the fiscal exchange, partially depends on one's trust that the money will be used appropriately. By contrast, among those who said they would not contribute more money, half claimed it was because they did not believe they would ever see a difference and claimed they already paid too much. As one 25-34 year-old woman selling from a shop expressed, "If 
even I pay, they won't do it" while a 55-64 year-old vending from a table stated, "We are being forced to move to nowhere so I don't see why I should contribute anything." ${ }^{25}$ In fact, while socioeconomic status makes a difference on willingness to pay, Figure 5 illustrates that even among those at the top of the socioeconomic index and who trust their MMDA are 62.5 percent likely to pay more compared with a likelihood of 49.1 percent for those with the same status but who distrust their MMDA.

Table 4: Implications of Trust

\begin{tabular}{|c|c|c|}
\hline Independent variables & $\begin{array}{l}\text { Willing to pay more for } \\
\text { priority service }\end{array}$ & $\begin{array}{l}\text { Would consult } \\
\text { MMDA first if service } \\
\text { provision was } \\
\text { problematic }\end{array}$ \\
\hline Trust MMDA & $\begin{array}{l}0.553+ \\
(0.30)\end{array}$ & $\begin{array}{l}0.953^{* *} \\
(0.35)\end{array}$ \\
\hline Service index of market ${ }^{\mathrm{a}}$ & $\begin{array}{l}-0.227 \\
(0.21)\end{array}$ & $\begin{array}{l}0.131 \\
(0.30)\end{array}$ \\
\hline $\begin{array}{l}\text { Socioeconomic status of } \\
\text { trader }\end{array}$ & $\begin{array}{l}0.126+ \\
(0.07)\end{array}$ & $\begin{array}{l}0.021 \\
(0.10)\end{array}$ \\
\hline Owner of stall or store & $\begin{array}{l}0.204 \\
(0.32)\end{array}$ & $\begin{array}{l}-0.522 \\
(0.73)\end{array}$ \\
\hline$N$ & 601 & 601 \\
\hline
\end{tabular}

Cluster bootstrapped standard errors in parentheses

${ }^{+} p<0.10,{ }^{*} p<0.05,{ }^{* *} p<0.01,{ }^{* * *} p<0.001$

Notes: ${ }^{a}$ This index captures whether respondents have access in the markets where they trade to the following three key services relevant for food safety: garbage collection, toilets, and drainage during the rainy season.

${ }^{25}$ Survey respondents T02720 and K041, respectively. 


\section{Figure 5: Likelihood of Paying More to MMDA by Trust and Socioeconomic Status}

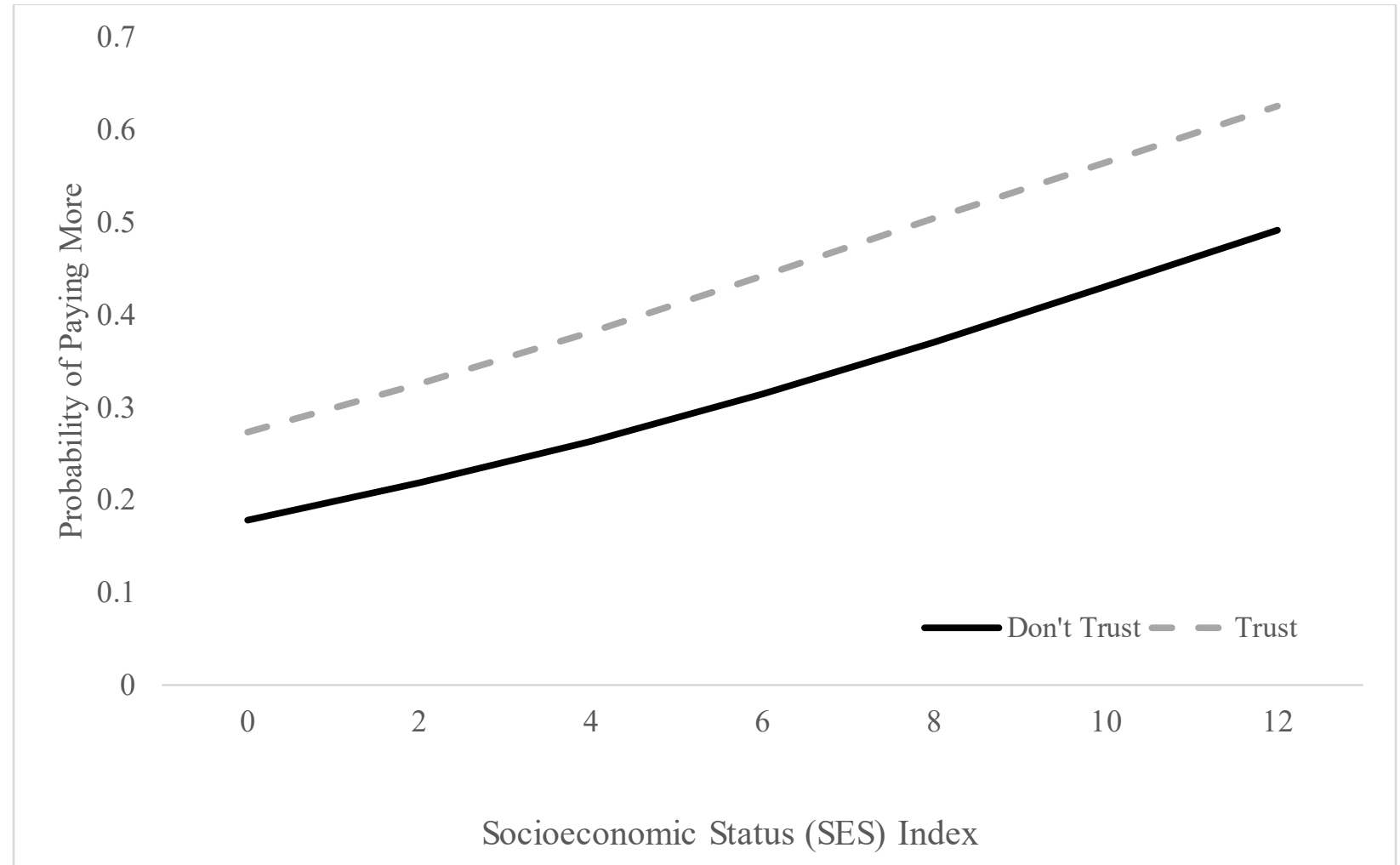

Notes: The dependent variable is the probability of a trader paying more to the respective MMDA in order to have his/her priority service issue addressed in the markets.

Relatedly, respondents were asked who they would consult if they were dissatisfied with services in the market. Again, those who expressed a degree of trust in their MMDA were more inclined to consult the MMDA in such a situation compared to those who lacked that trust. Such an association is revealing about the importance of trust in shaping citizen perceptions about government responsiveness.

\section{Conclusions}

The ways in which social contracts are forged with citizens affects their levels of political trust by shaping future expectations based on past experiences of reciprocity and procedural justice. Paying requisite taxes, fees, and licenses can undermine trust if respondents never see any benefits from the state in exchange for such payments. Such exchanges have been at the 
cornerstone of the social contract for industrialized countries, and they appear to be just as salient in developing country settings as well. This mechanism affected trust in all three cities examined here but was most pronounced in Accra where a high share of traders reported that their closest interaction with local government was through revenue authorities.

Furthermore, political trust is undermined by perceptions of discrimination by political authorities who do not seem to enforce laws relevant to informal food trade in an impartial manner. Experience with harassment can affect whether one views political authorities as legitimate representatives of the needs of the urban poor. This dynamic was especially significant in Kumasi where local authorities have a long history of targeting traders with violence and where a higher share of traders reported interacting with the task force than in the other cities.

Notably, these trust assessments were not associated with associational membership. This suggests that the personalized trust that may be fostered through social capital does not always translate into political trust. Associations of informal workers play many important functions for their members and sometimes extract concessions from the state. However, they are insufficient alone for building political trust, especially if they have had contentious relationships with government authorities in the past or only represent a small fraction of those operating in the informal economy.

Furthermore, trust in local government is not clearly correlated with capacity. Trust was highest in Tamale, which has the lowest rates of revenue collection from traders and the lowest ratio of task force officials to vendors. This supports other studies focused at the national level that argue that trust is not purely a metric of objective service provision that would reflect a state's level of human and financial resources (Brinkerhoff, Wetterberg, and Wibbels 2016; Mcloughlin 2015). 
As many countries in Africa and elsewhere continue to deepen their decentralization processes (OECD/UCLG 2016), trust can be a critical factor in determining whether the goals of enhanced political participation and engagement integral to decentralization actually materialize. Particularly for the urban poor, seeing the manifestations of the social contract created by their local governments as fair and responsive to their needs, and not just to those of the affluent, will be key for forging inclusive cities. While the current study focused on this for traders, it is equally relevant for the region's slum dwellers, informal transport providers, and others with vulnerable livelihoods whose contributions are nonetheless central to urban economies.

More broadly, the study suggests that important nuances are lost by failing to examine subnational variations in outcomes of interest, especially in countries where local governments have substantial autonomy to make policy decisions. Currently, there are few cross-city comparisons of urban governance in developing country settings. Yet, as global development initiatives continue to accord city governments with agenda-setting authority over major policy goals (Barber 2014; Schragger 2016), ranging from tackling climate change to nutrition, it is increasingly necessary to understand whether local governments are viewed as legitimate entities by their heterogeneous constituencies to deliver on these goals. 


\section{References}

Ackah, M, T Gyamfi, K Anim, et al. 2011. "Socioeconomic Profile, Knowledge of Hygiene and Food Safety Practices among Street Food Vendors in Some Parts of Accra, Ghana." Internet journal of food safety 13: 191-97.

Adamtey, N. 2015. Informal Economy Budget Analysis: Accra Metropolis WIEGO Working Papers. www.wiego.org.

Agarwala, R. 2013. Informal Labor, Formal Politics, and Dignified Discontent in India. Cambridge, UK: Cambridge University Press.

Awo, M. 2012. Marketing and Market Queens: A Study of Tomato Farmers in the Upper East Region of Ghana. Munster, Germany : LIT Verlag.

Baah-Ennumh, T, and G Adom-Asamoah. 2012. "The Role of Market Women in the Informal Urban Economy in Kumasi." Journal of Science and Technology (Ghana) 32(2).

Barber, B. 2014. If Mayors Ruled the World: Dysfunctional Nations, Rising Cities. New Haven, CT: Yale University Press.

Battersby, J, and J Crush. 2015. “Africa's Urban Food Deserts.” Urban Forum 25(2): 143-51.

Bell, D, and A De-Shalit. 2012. The Spirit of Cities: Hy the Identity of a City Matters in a Global Age. Princeton, NJ: Princeton University Press.

Bob-Milliar, GM, and F Obeng-Odoom. 2011. "The Informal Economy Is an Employer, a Nuisance, and a Goldmine: Multiple Representations of and Responses to Informality in Accra, Ghana." Urban Anthropology 40(3-4): 263-84.

van den Boogaard, V, W Prichard, and S Jibao. 2019. "Informal Taxation in Sierra Leone: Magnitudes, Perceptions and Implications." African Affairs 118(471): 259-84.

Brinkerhoff, DW, A Wetterberg, and E Wibbels. 2016. "Distance, Services, and Citizen Perceptions of the State in Rural Africa." Governance 31(1): 103-24.

Bromley, R. 2000. "Street Vending and Public Policy: A Global Review." International Journal of Sociology and Social Policy2 20: 1-28.

Brown, A, M Lyons, and I Dankoco. 2010. "Street Traders and the Emerging Spaces for Urban Voice and Citizenship in African Cities.” Urban Studies 47(3): 666-83.

Brown, A, C Msoka, and I Dankoco. 2015. “A Refugee in My Own Country: Evictions or Property Rights in the Urban Informal Economy?" Urban Studies 52(12): 2234-49.

Chowdhury, SR. 2003. "Old Classes and New Spaces: Urban Poverty, Unorganised Labour and New Unions." Economic and Political Weekly 38(50): 5277-84.

Clark, G. 2018. “African Market Women, Market Queens, and Merchant Queens.” In Oxford Research Encyclopedia of African History, Oxford University Press. http://oxfordre.com/africanhistory/view/10.1093/acrefore/9780190277734.001.0001/acrefor e-9780190277734-e-268. 
Clark, GC. 2013. "Twentieth-Century Government Attacks on Food Vendors in Kumasi Ghana." In Street Economies in the Urban Global South, eds. Karen Tranberg Hansen, Walter Little, and Gracia Clark. Santa Fe, NM: School for Advance Research Press, 29-48.

Cleary, M, and S Stokes. 2009. "Trust and Democracy in Comparative Perspective." In Whom Can We Trust? How Groups, Networks, and Institutions Make Trust Possible, eds. Karen Cook, Margaret Levi, and Russell Hardin. New York: Russell Sage Foundation.

Cook, KS, R Hardin, and M Levi. 2005. Cooperation Without Trust? New York: Russell Sage Foundation.

Copus, C, M Wingfield, K Steyvers, et al. 2012. "A Place to Party?: Parties and Nonpartisanship in Local Government." In The Oxford Handbook of Urban Politics, eds. Peter John, Karen Mossberger, and Susan Clarke. Oxford, UK: Oxford University Press, 1-26.

Corbridge, S. 2005. Seeing the State: Governance and Governmentality in India. New York, NY: Cambridge University Press.

Crush, J, and B Frayne. 2011. "Supermarket Expansion and the Informal Food Economy in Southern African Cities: Implications for Urban Food Security." Journal of Southern African Studies 37(4): 781-807.

Crush, J, and G Young. 2019. “Resituating Africa's Urban Informal Food Sector.” Urban Forum. https://doi.org/10.1007/s1213.

Delhey, J, and K Newton. 2003. "Who Trusts? The Origins of Social Trust in Seven Societies." European Societies 5(2): 93-137.

Devarajan, S, and E Ianchovichina. 2018. "A Broken Social Contract, Not High Inequality, Led to the Arab." Review of Income and Wealth 64(Spring): S5-25.

Devereux, S. 2013. "Trajectories of Social Protection in Africa." Development Southern Africa 30(1): 13-23.

FAO. 2016. Street Food Vending in Accra, Ghana Field Survey Report. Rome, Italy : Food and Agriculture Organization (FAO).

Fitzgerald, J, and J Wolak. 2016. "The Roots of Trust in Local Government in Western Europe." International Political Science Review 37(1): 130-46.

Fjeldstad, O-H. 2004. "What's Trust Got to Do with It? Non-Payment of Service Charges in Local Authorities in South Africa." Journal of Modern African Studies 42(4): 539-62.

Freeman, S. 2012. "Social Contract Approaches." The Oxford Handbook of Political Philosophy (September): 1-20.

Freitag, M, and R Traunmüller. 2009. "Spheres of Trust: An Empirical Analysis of the Foundations of Particularised and Generalised Trust." European Journal of Political Research 48(6): 782-803.

Frye, T, and E Borisova. 2019. "Elections, Protest, and Trust in Government: A Natural Experiment from Russia." Journal of Politics2 81(3): 820-32. 
Gershtenson, J, J Ladewig, and D Plane. 2006. "Parties, Institutional Control, and Trust in Government.” Social Science Quarterly 87(4): 882-902.

Ghana Statistical Service. 2014. Ghana Living Standards Survey Round 6.

Gillespie, T. 2016. "Accumulation by Urban Dispossession: Struggles over Urban Space in Accra, Ghana." Transactions of the Institute of British Geographers 41(1): 66-77.

Glasser, M, and S Berrisford. 2015. "Improving Delivery in Development: The Role of Voice, Social Contract, and Accountability." In The World Bank Legal Review Volume 6 Improving Delivery in Development: The Role of Voice, Social Contract, and Accountability, eds. Jan Wouters, Alberto Ninio, Teresa Doherty, and Cisse Hassane. Washington, DC: World Bank, 3-35.

Grimes, M. 2016. "Procedural Fairness and Political Trust." In Handbook on Political Trust, eds. S. Zmerli and T. van der Meer. Chelton, UK: Edward Elgar Publishing Limited.

GTUC. 2012. Women in Informal Economy Law Project: A Report on Street Vending in Ghana. Accra, Ghana: Ghana Trade Unions Congress.

Haggard, S, and N Birdsall. 2002. "The Social Contract and the Middle Class in East Asia." In When Markets Fail: Social Policy and Economic Reform, eds. Ethan Kapstein and Branco Milanovic. New York, NY: Russell Sage Foundation, 58-101.

Haggard, S, and R Kaufman. 2009. Development, Democracy, and Welfare States: Latin America, East Asia, and Eastern Europe. Princeton, NJ: Princeton University Press.

Hakverdian, A, and Q Mayne. 2012. "Institutional Trust, Education, and Corruption: A MicroMacro Interactive Approach.” Journal of Politics 74(3): 739-50.

Hardin, R. 1993. "The Street-Level Epistemology of Trust." Politics and Society 21(December): 505-29.

Harding, R. 2020. Rural Democracy: Elections and Developing in Africa. Oxford, UK: Oxford University Press.

Heller, P. 2000. "Degrees of Democracy: Some Comparative Lessons from India.” World Politics 52: 484-519.

De Herdt, T, K Titeca, and I Wagemakers. 2012. "Make Schools, Not War? Donors' Rewriting of the Social Contract in the DRC." Development Policy Review 30(6): 681-701.

Hetherington, MJ. 1998. "The Political Relevance of Political Trust.” American Political Science Review 92(4): 791-808.

Hickey, S. 2012. "The Politics of Social Protection: What Do We Get from a 'social Contract' Approach?” Canadian Journal of Development Studies 32(4): 426-38.

Hickey, S, and S King. 2016. "Understanding Social Accountability: Politics, Power and Building New Social Contracts.” Journal of Development Studies 52(8): 1225-40. http://dx.doi.org/10.1080/00220388.2015.1134778. 
Huang, F. 2018. "Using Cluster Bootstrapping Ot Analyze Nested Data with a Few Clusters." Educational and Psychological Measurement 78(2): 297-318.

ILO. 2018. Women and Men in the Informal Economy: A Statistical Picture. Geneva, Switzerland.

Inglehart, R. 2003. Human Values and Social Change: Findings from the Values Surveys. Leiden, The Netherlands: Brill.

International Food Policy Research Institute. 2020. "Informal Food Retail Trade in Ghanaian Cities."

Jennings, K. 1998. "Political Trust and the Roots of Devolution." In Trust and Governance, eds. Valerie Braithwaite and Margaret Levi. New York: Russell Sage Foundation, 77-101.

King, R. 2006. "Fulcrum of the Urban Economy: Governance and Street Livelihoods in Kumasi, Ghana." In Contested Space: Street Trading, Public Space, and Live- Lihoods in Developing Cities, ed. Alison Brown. Rugby, UK: ITDG Publishers, 100-118.

Lefebvre, H. 1968. "The Right to the City.” In Writings on Cities, eds. E. Kofman and E. Lebas. London, UK: Blackwell, 63-184.

Lessnoff, M. 1986. Social Contract. London, UK: Macmillan Education Ltd.

Levi, M. 1997. Consent, Dissent and Patriotism. New York, NY: Cambridge University Press.

Levi, M, A Sacks, and T Tyler. 2009. "Conceptualizing Legitimacy, Measuring Legitimating Beliefs.” American Behavioral Scientist 53(3): 354-75.

Locke, J. 1980. Second Treatise of Government. ed. C.B. Macpherson. Indianapolis, IN: Hackett.

Lyon, F. 2003. "Trader Associations and Urban Food Systems in Ghana: Institutionalist Approaches to Understanding Urban Collective Action." International Journal of Urban and Regional Research 27(1): 11-23.

Marien, S, and M Hooghe. 2011. "Does Political Trust Matter? An Empirical Investigation into the Relation between Political Trust and Support for Law Compliance." European Journal of Political Research 50(2): 267-91.

Mattes, R, and A Moreno. 2018. The Oxford Handbook of Social and Political Trust Social and Political Trust in Developing Countries: Sub-Saharan Africa and Latin America.

McCandless, E. 2018. Forging Resilient Social Contracts 179. New York, NY: United National Development Program.

Mcloughlin, C. 2015. "When Does Service Delivery Improve the Legitimacy of a Fragile or Conflict-Affected State?" Governance 28(3): 341-56.

Meagher, K. 2018. “Taxing Times: Taxation, Divided Societies and the Informal Economy in Northern Nigeria." Journal of Development Studies 54(1): 1-17. https://doi.org/10.1080/00220388.2016.1262026.

van der Meer, TWG. 2017. "Political Trust and the 'Crisis of Democracy."' Oxford Research Encyclopedia of Politics (October): 1-22. 
Mills, C. 1997. The Racial Contract. Ithaca, NY: Cornell University Press.

Mishler, W, and R Rose. 1997. "Trust, Distrust and Skepticism: Popular Evaluations of Civil and Political Institutions in Post-Communist Societies.” The Journal of Politics 59(2): 418-51.

Moore, M, W Prichard, and O-H Feldstad. 2018. Taxing Africa: Coercion, Reform, and Development. London, UK: Zed Books.

Newton, K, D Stolle, and S Zmerli. 2018. "Social and Political Trust.” In The Oxford Handbook of Social and Political Trust, ed. Eric Uslaner. Oxford, UK: Oxford University Press, 3756.

Norris, P. 2011. Critical Citizens: Global Support for Democratic Government. New York: Oxford University Press.

Nugent, P. 2010. "States and Social Contracts in Africa.” New Left Review 63(63): 35-68.

Obeng-Odoom, F. 2011. “The Informal Sector in Ghana under Siege." Journal of Developing Societies 27(3-4): 355-92.

OECD/UCLG. 2016. Subnational Governments around the World: Structure and Finance. Paris and Barcelona: OECD and United Cities and Local Governments (UCLG).

Olken, B, and M Singhal. 2011. "Informal Taxation.” American Economic Journal: Applied Economics 3(4): 1-28. https://www.ncbi.nlm.nih.gov/pmc/articles/PMC3243951/.

Osei-Boateng, C. 2019. Informal Workers and Social Dialogue in Ghana: The Case of UNIWA and the Accra Metropolitan Assembly. Amsterdam, The Netherlands.

Pateman, C. 1988. The Sexual Contract. Palo Alto, CA: Stanford University Press.

Paxton, P, and RW Ressler. 2017. "Trust and Participation in Associations." The Oxford Handbook of Social and Political Trust (September): 149-72.

Prichard, W. 2015. Taxation, Responsiveness, and Accountability in Developing Countries: The Dynamics of Tax Bargaining. New York, NY: Cambridge University Press.

- 2019. "Tax, Politics, and the Social Contract in Africa." Oxford Research Encyclopedia of Politics (October): 1-26.

Putnam, R. 2000. Bowling Alone: The Collapse and Revival of American Community. New York, NY: Simon and Schuster.

Putnam, R, R Leonardi, and R Nanetti. 1993. Making Democracy Work: Civic Traditions in Modern Italy. Princeton, NJ: Princeton University Press.

Rahn, WM, and TJ Rudolph. 2005. “A Tale of Political Trust in American Cities.” The Public Opinion Quarterly 69(4): 530-60.

Rawls, J. 1971. A Theory of Justice. Cambridge, MA: Harvard University Press.

Resnick, D. 2015. “The Political Economy of Africa's Emergent Middle Class: Retrospect and Prospects." Journal of International Development 27(5): 573-87. 
. 2019. "The Politics of Crackdowns on Africa's Informal Traders." Comparative Politics 52(1): 21-51.

Rothstein, B, and D Stolle. 2008. "The State and Social Capital: An Institutional Theory of Generalized Trust." Comparative Politics 40(4): 441-59.

Rousseau, JJ. 1997. The Social Contract and Other Later Political Writings. ed. Victor Gourevitch. Cambridge, UK: Cambridge University Press.

Sacks, A. 2011. The Antecedents of Approval, Trust and Legitimating Beliefs in Sub-Saharan Africa, Latin America and Six Arab Countries. Washington, DC: World Bank.

Sanchez, M, and R Senderowitsch. 2012. The Political Economy of the Middle Class in the Dominican Republic: Individualization of Public Goods, Lack of Institutional Trust, and Weak Collective Action. Washington, DC.

Schoeneberger, JA. 2016. "The Impact of Sample Size and Other Factors When Estimating Multilevel Logistic Models." The Journal of Experimental Education 84: 373-97.

Schragger, R. 2016. City Power: Urban Governance in a Global Age. Oxford, UK: Oxford University Press.

Skinner, C. 2019. "Contributing yet Excluded?: Informal Food Retail in African Cities." In Urban Food Systems Governance and Poverty in African Cities, eds. Jane Battersby and Vanessa Watson. Abingdon, Oxon, 104-15.

Smit, W. 2016. "Urban Governance and Urban Food Systems in Africa: Examining the Linkages.” Cities 58: 80-86. http://dx.doi.org/10.1016/j.cities.2016.05.001.

Steel, W, T Ujoranyi, and G Owusu. 2014. "Why Evictions Do Not Deter Street Traders: Case Study in Accra, Ghana." Ghana Social Science Journal 11: 52-76.

Stren, R. 2012. "Cities and Politics in the Developing World: Why Decentralization Matters." In Oxford Handbook of Urban Politics, eds. Peter John, Karen Mossberger, and Susan Clarke. Oxford, UK: Oxford University Press.

Sunshine, J, and T Tyler. 2003. "The Role of Procedural Justice and Legitimacy in Shaping Public Support for Policing." Law and Society Review 37(3): 513-47.

Tang, M, and N Huhe. 2016. "The Variant Effect of Decentralization on Trust in National and Local Governments in Asia." Political Studies 64(1): 216-34.

Tshitereke, C. 2006. The Experience of Economic Redistribution: The Growth, Employment and Redistribution Strategy in South Africa. London, UK: Routledge.

Tyler, T, K Rasinski, and K McGraw. 1985. "The Influence of Perceived Injustice on the Endorsement of Political Leaders.” Journal of Applied Social Psychology 15(8): 700-725.

Tyler, TR. 2001. "Public Trust and Confidence in Legal Authorities: What Do Majority and Minority Group Members Want from the Law and Legal Authorities?" Behavioral Sciences \& the Law 19: 215-35. 
UN. 2010. The State of African Cities 2010: Governance, Inequality and Urban Land Markets. Nairobi, Kenya: UN-Habitat.

Uslaner, E. 2002. The Moral Foundations of Trust. New York, NY: Cambridge University Press.

Williams, MJ. 2017. "The Political Economy of Unfinished Development Projects: Corruption, Clientelism, or Collective Choice?" American Political Science Review 111(4): 705-23.

Wolak, J, and CK Palus. 2010. "The Dynamics of Public Confidence in U.S. State and Local Government." State Politics and Policy Quarterly 10(4): 421-45.

World Bank. 2015. Rising through Cities in Ghana Ghana Urbanization Review Overview Report. Washington, DC: World Bank . www.worldbank.org.

—. 2019a. "DataBank."

https://databank.worldbank.org/reports.aspx?source=2\&series=EN.POP.SLUM.UR.ZS\&co untry $=\mathrm{SSF}$.

-2019b. Social Contracts and World Bank Country Engagements: Lessons from Emerging Practices. Washington, DC.

Wu, C, and R Wilkes. 2018. "Local-National Political Trust Patterns: Why China Is an Exception.” International Political Science Review 39(4): 436-54.

Yang, K, and M Holzer. 2006. "The Performance-Trust Link: Implications for Performance Measurement." Public Administration Review 66(1): 114-26. 


\section{ALL IFPRI DISCUSSION PAPERS}

All discussion papers are available here

They can be downloaded free of charge

INTERNATIONAL FOOD POLICY RESEARCH INSTITUTE www.ifpri.org

IFPRI HEADQUARTERS

1201 Eye Street, NW

Washington, DC 20005 USA

Tel.: +1-202-862-5600

Fax: +1-202-862-5606

Email: ifpri@cgiar.org 